\title{
Teachers' views and experiences on mathematical literacy and context-based task
}

\author{
Tatag Yuli Eko Siswono ${ }^{1}$, Sugi Hartono ${ }^{2}$, Ahmad Wachidul Kohar ${ }^{3}$, Abdul Haris Rosyidi ${ }^{4}$, Pradnyo Wijayanti ${ }^{5}$ \\ Departement of Mathematics \\ Universitas Negeri Surabaya \\ Surabaya, Indonesia \\ 1'tatagsiswono@unesa.ac.id, ${ }^{2}$ sugihartonounesa@gmail.com, ${ }^{3}$ ahmadw.kohar@gmail.com, ${ }^{4}$ abdulharis@ unesa.ac.id \\ ${ }^{5}$ pradnyowijayanti@unesa.ac.id
}

\begin{abstract}
This study aimed at exploring middle school mathematics teacher's views on mathematical literacy and context-based task. Data were collected through questionnaire items filled out by 91 teachers at two districts in East Java province, Indonesia. Data were analyzed by scoring the teacher responses and report the tendency of the responses on the concept of mathematical literacy and context-based task. The result indicates that in general, participants show high agreements on the conception which leads the characteristic of mathematical literacy and context-based task, except for the conception of the context-based task in relation to the level use of context and the scope of mathematical literacy. Regarding teachers' experience, teachers generally show a high degree of frequency in organizing mathematical literacy-based teaching, except for designing mathematics task using a particular context for mathematical literacy.
\end{abstract} views

Keywords-mathematical literacy, context-based task, teacher

\section{INTRODUCTION}

Mathematical literacy becomes a topic in mathematics education that goes beyond curricular mathematics and encompasses a broader conception of what constitutes mathematics. More specifically, it has also implied on daily practices in teaching mathematics. This topic has not only attract researchers on conceptualising the concepts related to mathematical literacy through investigating students' performance [1-2], but also extending the conception and application in teaching practice related to teacher education such as the exploration of teacher knowledge and view [3-4].

Supporting the notion that teacher learning on mathematical literacy knowledge should be placed as an important on professional training, Stacey [5] argued that teachers should have experienced mathematics in action by solving problems, conducting investigations and modeling the real world as a component of such knowledge needed for teaching. In addition, the view that teacher view on particular concept in teaching affect they way they hold instructional practice brings Thus, teachers' view and knowledge influence the successful of teaching which based on mathematical literacy.

In Indonesia, mathematical literacy become one of current emerging research topics for many researchers and policy makers. This is because of the increase of awareness for improving Indonesian students on developing this competence due to the insignificant improvement of PISA survey results during year 2000-2015 [5]. Such research topics were around exploring student performance on context-based task, i.e. a type of task used in PISA survey [1-2], developing PISA-like problems for learning resources [1,6], and exploring teacher view and practice on context-based task [3]. However, research on exploring teacher view on the conception of mathematical literacy as well as its practical teaching is scant. Thus, the extention of studying such conception needs further investigation.

This is a preliminary study of developing a model of professional development for supporting teachers' knowledge and practice in relation to mathematical literacy and creative thinking. In particular, this study concern on exploring teachers' views and experience on the concept of mathematical literacy and context-based task. The analysis of the results of this study would be then utilised as one of considerable factors of the frame of the professional develoment.

\section{THEORETICAL BACKGROUND}

\section{A. Mathematical Literacy}

The concept of mathematical literacy can be described as the competence of applying mathematics to everyday life. The defining feature of mathematical literacy is that it has to do with thinking mathematically while simultaneously thinking about the context in which the mathematics is being used [7]. One can view mathematical literacy as mathematics which is not only about it as a domain, but also it as an application in concrete and practical day-to-day existence [8].

The component procesess of mathematical literacy, i.e. formulating the problem mathematically, to solving it in mathematical solutions and then interpreting the solutions into real world context are particularly noted as the most important concepts inherent in the definition of mathematical literacy by PISA framework [9-10] Formally, PISA 2012 [9] defines mathematical literacy as an individual's capacity to formulate, employ and interpret mathematics in a variety of contexts. It includes reasoning mathematically and using mathematical concepts, procedures, facts and tools to describe, explain and predict phenomena. It assists individuals to recognize the role that mathematics plays in the world and to make the well- 
founded judgments and decisions needed by constructive, engaged and reflective citizens.

\section{B. Context-based task}

Van Den Heuvel-Panhuizen [11] provides two different meanings for the term 'context'. The first meaning of the context is the learning environment; this includes both the different situations in which learning takes place. The second meaning of the context is a characteristic of a task presented to the learner. In the context of this study, the term 'context' has been used to refer to the characteristics of the mathematical task

In this study, a context-based task refers to the task whose characteristics follow the nature of PISA task. Thus, the task refers to the nature of mathematical literacy. Some types of such task were recognized within international studies such as PISA task by OECD [9] and some research reports such as PISA-like task [1] and context-based task [2,12] Those types of task were developed by applying PISA framework.

With respect to the nature of mathematical literacy for PISA survey, PISA test developers, as Tout \& Spithill [13], admitted facing some challenges when posing PISA task. The challenges are the task should be (1) realistic and authentic (not seemingly artificial questions), (2) rich and interesting for 15year-olds around the world and were neither too hard nor too easy, and (3) were as much as possible equally accessible and equitable for students of different gender, culture, religion, living conditions, used appropriate and accessible language. Concerning on to the extent to which the authenticity of the task is expected to be emphasized in PISA-based task, PISA has used almost no zero-order context items [14]15], i.e. the items whose context is a mere camouflage, generally involves just mathematical terms, shapes, data and the translation of textually packaged mathematical problems. Rather, PISA used first order and second order use of context, each of whose context is respectively relevant and is needed for solving the problem and the knowledge of context is needed to "mathematize" the problem in order to solve it (OECD, 2009).

PISA framework 2012 particularly classifies PISA task by mentioning three domain categories: by the nature of the situation (the context category), the major domain of mathematics involved (the content category), and the major mathematical literacy process (the process category). Specifically, PISA divides the context category into four situations: personal, occupational, societal, and scientific; the content category into four contents: quantity, space and shape, change and relationship, and uncertainty and data; the process category into three processes: formulate, employ, and interpret. More elaborated characteristics of those categories are explained by OECD [9].

\section{METHOD}

\section{A. The mathematical literacy questionnaire}

The questionnaire was served as the central instrument of this study. It was designed collectively by the members of the survey's research team and validated by the experts in mathematics education outside the team, thus guaranteeing the content validity of the tool. It includes four sections:

Section A of the questionnaire aimed at collecting data on teachers' views on the concept of mathematical literacy. Section B of the questionnaire aimed at collecting data on teachers' views on context-based mathematics task. Section C of the questionnaire aimed at collecting data on teachers' experiences in organizing mathematical literacy-based instruction Section D of the questionnaire aimed at collecting data on teachers' experiences in designing a context-based mathematics task.

For Section A and B, participants were asked to express their agreement with each item of the questionnaire from "strongly disagree" (scored with 1) to "strongly agree" (scored 6). For section C and D, participants were asked to evaluate how often factors described in the questionnaire items are personally experienced by the teacher participants ranging from "never" (scored with 1) to "always" (scored with 6). The questionnaire's internal reliability was examined using Cronbach's alpha and the item validity was examined using product moment correlation.

\section{B. Participants}

As many as 91 mathematics teachers of middle schools from two districts in East Java province participated in this study. The number of year of teaching experience of each participant was also recorded $(\mathrm{M}=17.8, \mathrm{SD}=10.4)$, ranging from 1 year to 35 years.

\section{Data analysis}

Data were analyzed by scoring each of the responses from the participants for each item in all sections. The scoring was reported to inform the teacher participants' tendency toward the concept of mathematical literacy, context-based task and their experiences on those two concepts in daily teaching. Preceding this step, all the items were examined for its reliability and validity by employing SPSS 22 as the software for analysis.

\section{RESULTS AND DISCUSSION}

We start by reporting the examination of reliability and validity of the items of the questionnaire. Table 1 respectively show this results.

TABLE I. INTERNAL RELIABILITY OF THE QUESTIONNAIRE ITEMS

\begin{tabular}{|c|l|c|}
\hline Section & \multicolumn{1}{|c|}{ Category } & Chronbach's alpha \\
\hline A & $\begin{array}{l}\text { teachers' views on the concept of } \\
\text { mathematical literacy }\end{array}$ & 0.752 \\
\hline B & $\begin{array}{l}\text { teachers' views on context-based } \\
\text { mathematics task }\end{array}$ & 0.760 \\
\hline C & $\begin{array}{l}\text { teachers' experiences in organizing } \\
\text { mathematical literacy-based instruction }\end{array}$ & 0.935 \\
\hline D & $\begin{array}{l}\text { teachers' experiences in designing a } \\
\text { context-based mathematics task }\end{array}$ & 0.938 \\
\hline
\end{tabular}

Table 1 shows that all the sections in the questionnaire's internal reliability were examined using Cronbach's alpha, which it was found that the items are sufficiently high to 
perform statistical analysis for all categories. Also, The product-moment correlation analysis indicates that all the items of all sections are significantly valid at the 0.05 level (twotailed), $\mathrm{p}<0.05$.

In the following sections, Table 1, 2, 3 and 4 respectively depict the means and standard deviations for all the participating teachers in response to the four sections of the questionnaire.

\section{A. Teachers' views on the concept of mathematical literacy}

TABLE II. Responses To The ConcePt OF MATHEMATICAL Literacy

\begin{tabular}{|l|c|c|}
\hline \multicolumn{1}{|c|}{ Statements } & $* \mathbf{M}$ & $* *$ SD \\
\hline $\begin{array}{l}\text { I understand the term 'mathematical literacy' } \\
\text { well }\end{array}$ & 4.57 & 0.85 \\
\hline $\begin{array}{l}\text { Mathematical literacy is closely related to } \\
\text { context-based problem-solving activities }\end{array}$ & 5.14 & 0.61 \\
\hline Mathematical literacy is part of mathematics & 5.08 & 0.79 \\
\hline Mathematics is part of mathematical literacy & 4.55 & 1.16 \\
\hline $\begin{array}{l}\text { A learner with good mathematical abilities is } \\
\text { able to solve everyday problems related to } \\
\text { mathematics well }\end{array}$ & 5.02 & 0.82 \\
\hline $\begin{array}{l}\text { A learner who is able to solve everyday } \\
\text { problems related to mathematics well has } \\
\text { good math skills }\end{array}$ & 4.99 & 0.77 \\
\hline $\begin{array}{l}\text { Mathematical literacy is influenced by the } \\
\text { ability to understand information in the form } \\
\text { of text/reading }\end{array}$ & 5.10 & 0.82 \\
\hline $\begin{array}{l}\text { Mathematical literacy always starts from real } \\
\text { problems in everyday life }\end{array}$ & 4.93 & 1.06 \\
\hline $\begin{array}{l}\text { The focus of mathematical literacy is a } \\
\text { comprehensive understanding of various } \\
\text { branches of mathematics (calculus, geometry, } \\
\text { statistics, etc.) }\end{array}$ & 4.60 & 1.08 \\
\hline $\begin{array}{l}\text { The higher the ability of mathematical } \\
\text { literacy, the higher the ability to think } \\
\text { creatively }\end{array}$ & 5.34 & 0.70 \\
\hline
\end{tabular}

The highest degree of agreement is indicated in the statement about the relationship between mathematical literacy and creativity (5.34). This agreement supports the idea of causal relationship of the mathematical literacy in increasing creativity, in which this conception needs further explored. In relation to whether the scope of mathematics or mathematical literacy is bigger, the participants seem gave relatively same degree (between 5 and 6), which means both the two statements are interchangeable. This findings support the idea of mathematical literacy stated by Stacey and Turner [16] arguing for those who think that the mathematics is very limited on things abstract and theoretical, mathematical literacy is interpreted broader than mathematics since problem in mathematical literacy involves ability to link the world of formal abstract with real-world phenomena that later in deciding the solutions, one needs to consider both. For those who think the opposite, mathematical literacy is part of mathematics, the purpose of the activity of mathematics is functional and in tandem with this, there is an activity of mathematics whose purpose is to explore and understand the structures and patterns which are abstract for their own interests.

Likewise, with regards to the relationship between mathematics competence (formal world) and mathematical literacy (real world), the participants also indicate relatively same degree (item no 5 and 6), meaning that either mathematics competence or mathematical literacy are interdependent, i.e. influence each other.

Table 2 also reveals a relatively high degree on the conception that the focus of mathematical literacy is a comprehensive understanding of all the branches of mathematics, which leads teachers' misconception. Instead of such a conception, mathematical literacy, as Stacey [16] states, is not about a mathematics capability that is owned or not owned by anyone, but it is about something that each person develop in smaller or larger degree to take advantage of mathematics in everyday life.

\section{B. Teachers' views on the concept of context-based task}

TABLE III. Responses On THE ConcePt OF CONTEXT-BASED TASK

\begin{tabular}{|l|c|c|}
\hline \multicolumn{1}{|c|}{ Statements } & M & SD \\
\hline $\begin{array}{l}\text { Context-based problem motivates me learn } \\
\text { mathematics }\end{array}$ & 5.15 & 0.56 \\
\hline $\begin{array}{l}\text { Context-based problem relates mathematics to } \\
\text { the world of work }\end{array}$ & 4.90 & 0.83 \\
\hline $\begin{array}{l}\text { Context-based problem are good to be used as } \\
\text { learning resources in initiating learning }\end{array}$ & 5.20 & 0.65 \\
\hline Solving context-based problems is difficult & 3.54 & 1.14 \\
\hline $\begin{array}{l}\text { Difficulty in solving context-based problems } \\
\text { occurs when understanding problems in the } \\
\text { problem }\end{array}$ & 4.59 & 0.95 \\
\hline $\begin{array}{l}\text { Difficulty in solving context-based problems } \\
\text { occurs when creating the right mathematical } \\
\text { model according to the problem in the problem }\end{array}$ & 4.77 & 0.84 \\
\hline $\begin{array}{l}\text { Difficulty in solving context-based problems } \\
\text { occurs when performing mathematical } \\
\text { procedures in accordance with the mathematical } \\
\text { model that has been found }\end{array}$ & 4.46 & 1.01 \\
\hline $\begin{array}{l}\text { Difficulty in solving context-based problems } \\
\text { occurs when interpreting the mathematical results } \\
\text { obtained back to the initial context }\end{array}$ & 4.55 & 0.95 \\
\hline Designing context-based problem is difficult & 3.87 & 1.10 \\
\hline $\begin{array}{l}\text { The difficulty of creating context-based problem } \\
\text { is determining the suitable context that matches } \\
\text { the mathematical content that you want to test }\end{array}$ & 4.74 & 0.79 \\
\hline $\begin{array}{l}\text { Difficulty in creating context-based problem is } \\
\text { composing effective sentences }\end{array}$ & 4.58 & 0.98 \\
\hline $\begin{array}{l}\text { The use of real-world context makes me more } \\
\text { creative in creating math problems }\end{array}$ & 5.11 & 0.60 \\
\hline $\begin{array}{l}\text { Learning context-based problem helps me } \\
\text { understand certain mathematical concepts }\end{array}$ & 0.69 \\
\hline $\begin{array}{l}\text { Good mathematical understanding can always } \\
\text { help solve context-based problems }\end{array}$ & 0.60 \\
\hline $\begin{array}{l}\text { Pay attention to the following problem. } \\
\text { "A closed rectangular arena with a size of } 100 ~ m \\
x \text { 50 m will be used as } a \text { venue for concert } \\
\text { audiences. It was known that all spectators stood } \\
\text { and tickets were sold out. Estimate many } \\
\text { spectators present? } \\
\text { In my opinion, in order that a student solve the } \\
\text { problem, the question should need to be added } \\
\text { with explicit information about the size of the } \\
\text { lloor that someone needs to stand }\end{array}$ & 1.35 \\
\hline
\end{tabular}




\begin{tabular}{|l|l|l|}
\hline \multicolumn{1}{|c|}{ Statements } & M & SD \\
\hline $\begin{array}{l}\text { Pay attention to the following problem. } \\
\text { "Two wheels of the same diameter rotate with a } \\
\text { different number of rounds per minute. Wheel A } \\
\text { rotates 45 times every } 1 \text { minute, while wheel B }\end{array}$ & & \\
rotates 60 times every 2 minutes. Which wheel & 4.41 & 1.13 \\
rotates faster? " & & \\
The question can be categorized into a context- & & \\
based problem & & \\
\hline $\begin{array}{l}\text { Pay attention to the following problem } \\
\text { "Joni works full time for } 5 \text { days a week. He }\end{array}$ & & \\
spends Rp.450,000 every week for lunch & \\
including drinks. He finds a very similar place & & \\
for lunch, but not drinks. If he decides to have & & \\
lunch there, he will only spend Rp. 350,000 a & \\
week for lunch, but he must spend an additional & 4.81 & 0.83 \\
Rp. 500,000 per month on drinks. Based on this & & \\
information, should Joni have lunch in an & \\
ordinary place or try a new place? " & \\
The question can be categorized into a context- & & \\
based problem & & \\
\hline
\end{tabular}

Table 3 shows the teachers' view on context-based task. It is surprising that teachers only provide a relatively low degree of agreement on the difficulties in solving and designing context-based task (below score 4), in which this is contrasted with the teachers' performance on context-based task we previously studied in the same population [17]. However, in relation to personal and teaching factors such as context-based task increase motivation, good for learning resources, connect to real-world need, and increase creativity, the participants responded a high degree of agreement (more than 5). Along the same lines, they also responded a high agreement on the difficulties in solving context-based task such as around formulating a precise mathematical model, employing mathematical facts and procedures, as well as interpreting mathematical results back to the initial problem.

Teachers' views on the characteristics of context-based task are provided at no 15-17. In sum, teachers do not yet fully understand about the context-based task which regards to the concept of mathematical literacy. While the teachers gave high agreement on the item no 17 , which is indeed a context-based problem having a first degree of context level, they also gave high agreement on item no 16, which is not suitable for mathematical literacy since it has camouflage context (zeroorder use of context). In addition, teachers also tend to agree that the context-based task as shown in item no 15 need to have a more explicit information about particular assumption, which leads students might not have a wider opportunity to generate students' own contextual knowledge on the higher level use of context-based task.

\section{Teachers' experiences on mathematical literacy-based teaching}

TABLE IV. RESPONSES OF TEACHERS' EXPERIENCE ON MATHEMATICAL LITERACY-BASED TEACHING

\begin{tabular}{|c|c|c|c|}
\hline Num & \multicolumn{1}{|c|}{ Statements } & M & SD \\
\hline In guiding students to solve context-based problem, I... & & \\
\hline 1 & $\begin{array}{l}\text { ask students to read the text of the question and } \\
\text { encourage them to pay attention to every } \\
\text { word/phrase contained in the information about }\end{array}$ & 5.27 & 0.80 \\
\hline
\end{tabular}

\begin{tabular}{|c|c|c|c|}
\hline Num & Statements & M & SD \\
\hline & the problem & & \\
\hline 2 & $\begin{array}{l}\text { ask students to explain the problem given to the } \\
\text { problem by using their own sentence either in } \\
\text { writing or verbally }\end{array}$ & 4.81 & 1.10 \\
\hline 3 & $\begin{array}{l}\text { encourage students to find the relationship } \\
\text { between the information contained in the } \\
\text { problem and their initial knowledge. }\end{array}$ & 4.85 & 0.91 \\
\hline 4 & $\begin{array}{l}\text { encourage students to find a collection of } \\
\text { information needed and not needed }\end{array}$ & 4.68 & 1.05 \\
\hline 5 & $\begin{array}{l}\text { stimulate students to find strategies that might be } \\
\text { used to solve problems. }\end{array}$ & 4.87 & 0.79 \\
\hline 6 & $\begin{array}{l}\text { ensure that each student/group has determined a } \\
\text { strategy or plan for problem-solving }\end{array}$ & 4.53 & 0.92 \\
\hline 7 & $\begin{array}{l}\text { provide reinforcement or guidance to improve } \\
\text { the model/strategy determined by students }\end{array}$ & 4.69 & 1.11 \\
\hline 8 & $\begin{array}{l}\text { ask students to consider the truth of each } \\
\text { mathematical procedure and logic/step of } \\
\text { reasoning until they arrive at a particular } \\
\text { mathematical solution they find }\end{array}$ & 4.57 & 1.02 \\
\hline 9 & $\begin{array}{l}\text { encourage students to determine the } \\
\text { reasonableness of the solution obtained by } \\
\text { relating it to the context of the problem }\end{array}$ & 4.46 & 1.01 \\
\hline 10 & $\begin{array}{l}\text { ask students to present their solutions to other } \\
\text { students in an effort to verify the fairness of the } \\
\text { solutions offered }\end{array}$ & 4.51 & 1.13 \\
\hline 11 & $\begin{array}{l}\text { ask students to reevaluate the steps that have } \\
\text { been done before and also consider possible } \\
\text { solutions, methods or other strategies that might } \\
\text { be used }\end{array}$ & 4.58 & 1.02 \\
\hline 12 & $\begin{array}{l}\text { encourage students to identify the strengths and } \\
\text { weaknesses of the solutions and strategies they } \\
\text { get to get the most effective strategies for solving } \\
\text { problems }\end{array}$ & 4.44 & 1.05 \\
\hline 13 & $\begin{array}{l}\text { giving students the opportunity to actively } \\
\text { discuss to help solve difficulties experienced by } \\
\text { students }\end{array}$ & 5.03 & 0.74 \\
\hline 14 & $\begin{array}{l}\text { together with students make conclusions about } \\
\text { problem-solving experiences by actively } \\
\text { involving students in drawing on reflections for } \\
\text { better problem-solving experiences }\end{array}$ & 5.10 & 0.83 \\
\hline 15 & $\begin{array}{l}\text { encourage students to pose new, more } \\
\text { complex/interesting math problems }\end{array}$ & 4.45 & 1.08 \\
\hline 16 & $\begin{array}{l}\text { encourage students to pose new mathematical } \\
\text { problems according to their own interests }\end{array}$ & 4.23 & 1.04 \\
\hline
\end{tabular}

Table 4 describes the items depicting the sequential stages of guiding students solve context-based task in a mathematics instruction based on the mathematical literacy processes expected to be performed by students: formulating situations mathematically (no 1-7), employing mathematical facts/procedures/equations (no 8), and interpreting mathematical solutions back to the real world context (no 917). The latter group of processes, however, are extended to follow the recommendation of carrying out problem-solving instructon suggested by Mason [18], in which thought process (no 11-14) and problem extention (no 15-17) need to be also taken into account.

In general, the teacher participants admitted to having experience in organizing mathematical literacy-based teaching in high frequency between 4 to 6 (sometimes to always). The highest frequency is the experience of taking students to read any questions to understand the information required to solve the problem of the question (5.27), and the lowest frequency is the experience of encouraging students to pose new mathematical problems according to their own interests (4.23). 
The latter finding indicates that problem posing activities in the classroom teaching still get missed attention by teacher.

\section{Teachers' experiences on context-based task}

TABLE V. RESPONSES Of TEACHERS' EXPERIENCE ON CONTEXT-BASED TASK

\begin{tabular}{|c|l|c|c|}
\hline \multicolumn{1}{|c|}{ Statements } & \multirow{2}{*}{ M } & SD \\
\hline 1 & $\begin{array}{l}\text { In designing context-based problem, I... } \\
\text { use the context of stories from learner and } \\
\text { environmental life around students }\end{array}$ & 4.09 & 1.20 \\
\hline 2 & $\begin{array}{l}\text { using the context of stories from the world of } \\
\text { work }\end{array}$ & 4.03 & 1.12 \\
\hline 3 & $\begin{array}{l}\text { use the context of stories from social and cultural } \\
\text { life }\end{array}$ & 3.99 & 1.07 \\
\hline 5 & $\begin{array}{l}\text { using the context of stories from science } \\
\text { (physics, biology, chemistry, etc.) }\end{array}$ & $\begin{array}{l}\text { consider whether the situation in the problem that } \\
\text { I made really happened in the real world }\end{array}$ & 4.30 \\
\hline 6 & $\begin{array}{l}\text { departing from a new mathematical topic to adapt } \\
\text { it to the real world }\end{array}$ & 4.30 & 1.10 \\
\hline 7 & $\begin{array}{l}\text { departing from the real world just adjusting it to } \\
\text { the topic of mathematics }\end{array}$ & 4.35 & 0.94 \\
\hline
\end{tabular}

The items in table 4 were developed around subcategories of types of contexts as mentioned in PISA task (no 1-4), the existence of authentic contexts (no 5), and content or context resource as the priority of designing task (no 6-7).

Compared to teachers' experience on mathematical literacy-based teaching, the frequency of teachers' experience on designing context-based task are relatively lower (3.994.50) which means teacher does not often design context-based task which meets the criteria of task required by the items of section D. An interesting point is that designing context-based task, as participants responded in a relatively same degree of frequency, can be started from real world to mathematics topics or vice versa. Regarding the types of context for the contextbased task designed by teachers, the participants have relatively same degree of frequency toward the use of personal, occupational, societal, and scientific context.

\section{DISCUSSION AND CONCLUSION}

Results of this study indicate that teachers admit to have relatively high frequency of holding mathematics instruction aligned with mathematical literacy-besed teaching. In fact, this results is contrasted with some related findings of Indonesian teacher. Wijaya et al [3] found that Indonesian teachers at their study conducted mostly use directive approach, the approach which does not support mathematical literacy-based teaching, instead of consultative approach, the approach supporting mathematical literacy-based teaching, during guiding students solve context-based task. In line with such findings, Siswono et al [19] report that teacher's teaching practices of their selected teacher participants, even with problem-solving view, which support consultative teaching, have not fully met the requirements for consultative learning. Thus, there is inconsistency between teacher experience recognized from questionnaire result and from teaching practice observation.

To conclude, this paper highlight that in general, participants show high agreements on the conception which leads the characteristics of mathematical literacy and contextbased task, except for the conception of context-based task in relation to the level use of context and the scope of mathematical literacy. Regarding teachers' experience, teachers generally show a high degree of frequency in organizing mathematical literacy-based teaching, except for designing mathematics task using a particular context for mathematical literacy.

To suggest, the findings of this study encourage future research to study the consistency of teachers' experience as the teachers admit when participating in the questionnaire with teachers' real teaching practice. Also, future research may discuss the possible explanation of the views held by teachers as found in this study by carrying out a more deeply qualitative approach. Regarding the model of teacher professional development (TPD) that would be designed in the on going projects carried out by the authors of this study, the TPD should concern on minimizing the gap between teachers' teaching view and practice. This effort, for example, can be anticipated by considering the need of improving teach knowledge and beliefs by problem solving and problem activitis, such as programs for improving teachers' mathematics problem solving knowledge for teaching [20], and program for improving teachers' knowledge in posing context-based problem-solving task [21].

\section{ACKNOWLEDGMENT}

We thanks Ministry of Research and Higher Education for the grant within the scheme of research "Strategi Nasional 2018 " and all the participating teachers in this study.

\section{REFERENCES}

[1] Kohar, A.W., Zulkardi \& and Darmawijoyo. (2014) Developing PISALike Mathematics Tasks To Promote Students' Mathematical Literacy. In: Ratu Ilma (Eds), The Second South East Asia Design/ Development Research (SEA-DR) International Conference, April 26-27,2014, Unsri, Palembang, April 26th-27th,2014, Palembang

[2] Wijaya, A., van den Heuvel-Panhuizen, M., Doorman, M., \& Robitzsch, A. (2014). Difficulties in solving context-based PISA mathematics tasks: An analysis of students' errors. The Mathematics Enthusiast, 11(3), 555584.

[3] Wijaya, A., van den Heuvel-Panhuizen, M., \& Doorman, M. (2015) Teachers' teaching practices and beliefs regarding context-based tasks and their relation with students' difficulties in solving these tasks. Mathematics Education Research Journal, 27(4), 637-662.

[4] Siswono, T. Y. E., Kohar, A. W., \& Hartono, S. (2017, February). Secondary Teachers' Mathematics-related Beliefs and Knowledge about Mathematical Problem-solving. In Journal of Physics: Conference Series (Vol. 812, No. 1, p. 012046). IOP Publishing.

[5] Organisation for Economic Co-operation and Development (OECD). (2013a). PISA 2012 results: What students know and can do (Vol. I): Student performance in mathematics, reading, and science. Paris: PISA, OECD Publishing. doi:10.1787/9789264201118-en.

[6] Stacey, K., Almuna, F., Caraballo, R. M., Chesné, J. F., Garfunkel, S., Gooya, Z., ... \& Perl, H. (2015). PISA's influence on thought and action in mathematics education. In Assessing Mathematical Literacy (pp. 275 306). Springer, Cham.

[7] Stacey, K. (2008). Mathematics for secondary teaching: Four components of discipline knowledge for a changing teacher workforce in western countries. In Sullivan, P., \& Wood, T. (Eds.), International handbook of mathematics teacher education: Vol. 1. Knowledge and 
beliefs in mathematics teaching and teaching development. (pp. 87113). Rotterdam, The Netherlands:

[8] Mbekwa, M. (2006). Teachers' views on mathematical literacy and on their experiences as students of the course. Pythagoras, 2006(63), 22-29.

[9] Organisation for Economic Co-operation and Development (OECD). (2013b). PISA 2012 assessment and analytical framework: Mathematics, reading, science, problem-solving and financial literacy. Paris: $\mathrm{OECD}$ Publishing. doi:10.1787/9789264190511-en.

[10] Stacey, K. (2011). The PISA View of Mathematical Literacy in Indonesia, Journal on Mathematics Education (IndoMS-JME), 2(2),95126.

[11] Van den Heuvel-Panhuizen, M. (2005). The role of context in assessment problems in mathematics. For the Learning of Mathematics, 25(2).

[12] Ekawati, R., Kohar, A. W., \& Hartono, S. (2017). Experts' notion and students' responses on context-based mathematics problem. Journal of Engineering Science and Technology (JESTEC), 53-64.

[13] Tout, D., \& Spithill, J. (2015). The challenges and complexities of writing items to test mathematical literacy. In Stacey, K \& Turner R (Eds), Assessing Mathematical Literacy (pp. 145-171). Springer International Publishing.

[14] Salgado, F. A., \& Stacey, K. (2014). Item Context Factors Affecting Students' Performance on Mathematics Items. Mathematics Education Research Group of Australasia.

[15] Organisation for Economic Co-operation and Development (OECD). (2009). Learning mathematics for life: a perspective from PISA. Paris: PISA, OECD Publishing.
[16] Stacey, K., \& Turner, R. (2015). The evolution and key concepts of the PISA mathematics frameworks. In Assessing mathematical literacy (pp. 5-33). Springer, Cham.

[17] Siswono, T. Y. E., Kohar, A. W., Kurniasari, I., \& Astuti, Y. P. (2016, February). An Investigation of Secondary Teachers' Understanding and Belief on Mathematical Problem Solving. In Journal of Physics: Conference Series (Vol. 693, No. 1, p. 012015). IOP Publishing.

[18] Mason, J. (2015). On being stuck on a mathematical problem: What does it mean to have something come-to-mind?. LUMAT (2013-2015 Issues), 3(1), 101-121.

[19] Siswono, T. Y. E., Kohar, A. W., Kurniasari, I., \& Hartono, S. Inconsistency Among Beliefs, Knowledge, and Teaching Practice in Mathematical Problem Solving: A Case Study of a Primary Teacher. Southeast Asian Mathematics Education Journal 7(2) 27-39

[20] Siswono T Y E, Kohar A W, Hartono S, Rosyidi \& Masriyah 2018 An Innovative Training Model for Supporting In-service Teachers' Understanding on Problem-solving Knowledge for Teaching in Proceeding of EARCOME 8321

[21] Siswono, T. Y. E., Kohar, A. W., Rosyidi, A. H., \& Hartono, S. (2018, January). Searching for Authentic Context in Designing PISA-like Mathematics Problem: From Indoor to Outdoor Field Experience. In Journal of Physics: Conference Series (Vol. 953, No. 1, p. 012197). IOP Publishing. 